\title{
The Effects of Team Games Tournament Smart Cards Method to the Handwashing Knowledge with Soap Among 5-6 Years Old Preschoolers
}

\author{
Malpaleni Satriana \\ Lecture of Teacher Education Program For \\ Early Childhood Education, \\ MulawarmanUniversity, \\ Samarinda, Indonesia \\ malpa.mz@gmail.com \\ Aminuddin \\ Chairman of the Baitul Izzah Foundation, \\ Bengkulu, Indonesia \\ Ummi Salamah \\ Teacher of TKIT Baitul Izzah, \\ Bengkulu, Indonesia
}

\author{
Danti Mutia Sari \\ Graduatesof Public Health Faculty, \\ Mulawarman University, \\ Tarakan, Indonesia
}

Herawaty

Headmaster of TKIT Baitul Izzah, Bengkulu, Indonesia

Antung Dewi Nurliana Sagita

Early Childhood Education

Practitioner Rumah Pelangi Cendekia

Nusantara Foundation,

Samarinda, Indonesia

\author{
Ali Abubakar \\ Lecture of \\ Universitas Islam Negeri Ar-Raniry, \\ Banda Aceh, Indonesia
}

\author{
Kasbonati \\ Teacher of TKIT Baitul Izzah, \\ Bengkulu, Indonesia
}

\begin{abstract}
This research aims to reveal the knowledge of how 5-6 year old preschoolers wash their hands with soap by employing Team Games Tournament Smart Cards method in TKIT of Baitul Izzah Bengkulu. This research uses pre-experimental method with 33 preschoolers as the sample. The instrument used is a questionnaire and the data analysis utilizes $\boldsymbol{T}$-test as the alternative test with 5\% margin of error. The result of T-test from the handwashing knowledge with soap, before and after being given the Team Games Tournament Smart Card method is $p$ value $<\mathbf{0 , 0 4 3}$. The knowledge after being given the Team Games Tournament Smart Card method is 10,02. Therefore, it is concluded that the Team Games Tournament Smart Card method is proven effective in delivering knowledge about handwashing with soap among 56yearold preschoolers in TKIT of BaitulIzzah Bengkulu. It is expected that the Team Games Tournament Smart Card method can be an alternative in teaching the appropriate knowledge for preschoolers based on their age characteristics.
\end{abstract}

Keywords: handwashing with soap, Team Games Tournament Method, Smart Card

\section{INTRODUCTION}

Commonly, the diseases suffered by preschoolers in their playing neighborhood were related to the healthy and clean behavior. Diarrhea is one of the diseases linked to hygiene. Washing hands with soap is one of the ways to prevent diarrhea, which is often transmitted to children [1].

According to WHO date in 2017, diarrhea can kill approximately 525,000 toddlers every year and 1.7 billion cases of diarrhea killing children annually. In accordance with Indonesia health profile, there were approximately $6,897,463$ cases of people with $3.04 \%$ CFR in 2016, which increased when compared to $2.47 \%$ in 2015 [2]. Bengkulu had 52,225 diarrhea cases in 2017 [2]. In Bengkulu, diarrhea is one of the top 10 diseases with the most infection throughout 2017 with 6,202 cases [3].

One of the ways to prevent and decrease diarrhea is to wash hands with soap. Based on the intervention type, the effectiveness level of washing hands with soap in decreasing the number of people suffering from diarrhea is $44 \%$, higher than any other intervention types like the use of processed water by $39 \%$, sanitation by $32 \%$, health education by $28 \%$, water supply by $25 \%$, and sources of processed water by $11 \%$. Therefore, washing hands with soap is an effective intervention in preventing and decreasing diarrhea [4]. Socializations of washing hands with soap can lower the chance of diarrhea infection by $30 \%$ at the daycare center in countries with high, average and low revenue [5].

Fundamental Health Research Results in 2013 explains that the proportion of people above 10 years old who wash their hands correctly are only 47\% [6]. Most Indonesian People only wash their hands with water $(93,6$ $\%)$ compared to with soap $(66,0 \%)$. Most people who wash their hands when they are dirty are $70,9 \%$ while those washing their hands with soap every time are only $3,7 \%$. It applies similarly to washing hands after defecating, which is $33,9 \%$, and before having a meal [6].

This research employs Teams Games Tournament Method is a part of cooperative learning model which is a learning model that group children into smaller groups, cooperate with and help each other to understanding a learning materials [7]. Cooperative learning is working together to accomplish collective goals [8]. Teams Games Tournament Method has been used frequently in formal education level and proven effective in improving students' learning achievement [9]

This method has 5 stages in its execution, class presentation, team-learning, games, tournaments, and assessment/rewarding. One of the distinctions of this method from other cooperative learning methods is the games played by the children. The principle of learning 
while playing among preschoolers is an effective way to create an active and fun learning environment thus will affect the knowledge development. A game using flash card media is known as smart card. It is designed by the researcher and it contains 14 question cards, 14 answer cards and 28 picture cards of how to wash hands step by step[9].

Flashcard mostly contains words, pictures or both combined [10]. Based on Wasilah picture cards media are excellent to increase the students' learning enthusiasm, train their sensitivity towards an object and stimulate their imagination consequently it will be easy for them to recognize objects around them [11]. Knowledge is the result of sensing an object that can shape one's behavior towards it based on the knowledge they have obtained [12].

Children are behavior agents of change both at society and school in order to introduced and preserve environmental change [13]. World Washing Hands with Soap Campaign or International Washing Hands with Soap Day is a global campaign proposed by the United Nations incorporating with other organizations. It is expected to get people to fix their health practices in washing their hands with soap as a mean of decreasing the toddler's mortality rate and prevention from diseases that can potentially result in the quality degradation of human life quality. Hence, the habit of washing hands with soap needs to be taught to children [4].

Washing hands with soap is one of the sanitation actions that cleans hands starting from their fingers using water and soap by people to become clean and break the bacteria chain [14].

Kemenkes RI recommends to make washing hands with soap a habit which is before having a meal, after defecating, before preparing for meals, after playing and after coughing and sneezing [15]. Washing hands with soap can kill germs causing diseases, prevent diseases contagion (Diarrhea, worm infestation, URTI, typhus and SARS), as well as make hands clean [16]. Center of Disease Control and Prevention suggests to wash hands with soap before and after nursing a sick person, before and after treating wounds, after using a toilet, after touching animals, their food and fesses and after touching garbage [17].

The Teams Games Tournament method employing Tournament Question Cards media give the effect as much as $38,15 \%$ to the learning achievement of hydrocarbon and petroleum materials [18]. The Teams Games Tournament method implementation in learning finds out information quickly from various particular texts through scanning reading, reaching target across 3 cycles with $86,95 \%$ success [19].

\section{METHOD}

This research was carried out in TKIT of Baitul Izzah Bengkulu in May 2019. The research methodology used was pre-experimental. The population of this research was all 5-6 year old preschoolers in TKIT of Baitul Izzah Bengkulu with 33 preschoolers as the samples. Data was analyzed using t-test as the alternative test with $5 \%$ margin of errors.

\section{RESULTS AND DISCUSSION}

From all the observed 33 preschoolers respondents, it is visible the average knowledge before being given the Teams Games Tournament Smart Cards method was 56,16 and the average knowledge after being given the Teams Games Tournament Smart Cards method was 66,18 . The average difference of knowledge before and after being given the Teams Games Tournament Smart Cards method was $-10,02$ which means the knowledge after being given the Teams Games Tournament Smart Cards method is higher than before they were given the Teams Games Tournament Smart Cards method. It means there was 10,02 increase of knowledge after being given the Teams Games Tournament Smart Cards method. The statistic calculation result using dependent t-test, it was found that the $\mathrm{p}$-value is $0,043(\mathrm{p}=0,000<0,05)$ therefore there is an increase of knowledge before and after they were given the Teams Games Tournament Smart Cards method.

The collaborative or cooperative activities built by children will stimulate their cognitive development [9]. The use of interesting games method under a fun atmosphere will enable them to obtain information given [20]. Piaget states that learning is an active process and knowledge is set inside children's mind where a mind concept and impression are formed by thinking about an object and reacting to it [21]. Therefore, an education should essentially be able to enable and stimulate students' enthusiasm in exposing their potentials so there will be a desirable learning process where all of them can participate actively in the activities.

Paiget affirms that knowledge, values, regulations, morality can only be learned by having interactions with others. Thus, when children interact such as discussing with other people, both with the same age and older, there will be an interaction which serves as the change stimulus for them where they will try to rethink of their comprehension of a problem and reconstruct a new, more congruent and acceptable comprehension [8].

Knowledge increase can occur from the learning experience that children acquire. It will make them easier to understand the materials given to them. It can run well and accomplish the desired outcome when students can utilize all of their senses. The more senses involved to predict and process the incoming infor-mation, the bigger the change information can be understood and conserved [22].

\section{CONCLUSION}

As one of learning methods, Teams Games Tournament Smart Cards gives effects to the knowledge of washing hands with soap for preschoolers, increase their knowledge after being given Teams Games Tournament Smart Cards by 10,02.It is suggested, in giving variations in teaching learning processes, to consider the appropriateness of age level and children's characteristics. Teams Games Tournament Smart Cards method uses play-along process utilizing smart cards 
media to entertain them which consequently is effective to be used for preschoolers.

\section{REFERENCES}

[1] P. Atikah and E. Rahmawati. .Perilaku hidup bersih dan sehat (PHBS). Yogyakarta: Nuha Medika, 2012

[2] Kementerian Kesehatan Republik Indonesia. Profil Kesehatan Indonesia. Jakarta: Kemenkes RI, 2017

[3] Dinas Kesehatan. Profil Kesehatan Kota Bengkulu. Bengkulu: Dinkes Bengkulu, 2018

[4] Pusat Data dan Informasi Kementerian Kesehatan RI. Perilaku Mencuci Tangan Pakai Sabun di Indonesia. Jakarta: Pusdatin Kemenkes RI, 2014

[5] RI. Ejemot-Nwadiaro, Ehiri. JE, Arikpo. D, Meremkwu. MM, and Critchley. JA. Hand Washing Promotion for Preventing Diarrhea. Cochrane Library Systemic Reviews. Cochrane Library, vol. 9, pp. 1-95, 2015

[6] Unicef. Sanitation and Hand Washing Baseline and Knowledge, Attitudes, and Practice (KAP) Study in Support of the Strengthening Community Approaches to Total Sanitation (STBM) Project in Six Districts of Eastern Indonesia, 2014

[7] J.M. Asmani.. Tips Efektif Cooperative Learning. Yogyakarta: Diva Press, 2016

[8] M. Huda. Cooperative Learning Metode Teknik, Struktur dan Model Penerapan. Yogyakarta: Pustaka Pelajar, 2012

[9] R. E Slavin. Cooperative Learning. Bandung: Nusa Media, 2005

[10] W. Basuki and F. Mukti. Media Pengajaran. Jakarta:Depdikbud, 1992

[11] Masturi, F. Fakhriyah., M. Rosya., and I. Faturrohman. Pengarug Penggunaan Media Karu Bergambar terhadap Kemampuan Mendeskripsikan Daur Hidup Organisme Dilihat dari Tingkat Kemandirian Belajar Siswa di SD 5 Dersalam Kudus. University Muria Kudus, pp. 39-44, 2014

[12] Wawan. A, and Dewi M. Teori dan Pengukuran Pengetahuan, Sikap, dan Perilaku Manusia. Yogyakarta: Nuha Medika, 2010

[13] Pusat Promosi Kesehatan Departemen Kesehatan RI. Promosi Kesehatan di Sekolah. Jakarta: Pusat Promkes Depkes RI, 2018

[14] Pusat Data dan Informasi Kementerian Kesehatan RI. Perilaku Mencuci Tangan Pakai Sabun di Indonesia. Jakarta: PusdatinKemenkes RI, 2014

[15] Pusat Data dan Informasi Kementrian Kesehatan RI. Situasi Diare di Indonesia. Jakarta: Pusdatin Kemenkes RI, 2011

[16] Pusat Promosi Kesehatan Departemen Kesehatan RI. Rumah Tanga Sehat dengan Perilaku Hidup Bersih dan Sehat. Jakarta: Pusat Promkes Depkes RI, 2009

[17] U.S Departement of Health and Human Services. Centers for Disease Control and Prevention. Handwashing and Hand Sanitizer Use at Home, at Play, and Out and About, 2018. Available from: https://www.cdc.gov/handwashing/pdf/hand-sanitizer-factsheet.pdf

[18] Sari, ADC \& Supardi KS. Pengaruh Model Team Games Tournament Media Tournament Question Card Terhadap Hasil Belajar Siswa Pada Materi Hidrokarbon. Jurnal Inovasi Pendidikan Kimia Vol.7 No.2, 2013 (Universitas Negeri Semarang)

[19] Priatna, et. al. Penerapan Metode Team Games Tournament Dalam Pembelajaran Menemukan Informasi Secara Cepat Dari Berbagai Teks Khusus Melalui Membaca Memindai. Jurnal Pena Ilmiah Vo.2 No. 1, 2017. Bandung: Universitas Pendidikan Indonesia

[20] Pratiwi, dkk. Pengaruh Penyuluhan Metode Permainan Edukatif dan Metode Ceramah terhadap Pengetahuan, Sikap, dan Tindakan tentang Pencegahan Penyakit Diare pada Murid SD di Kecematan Poasia Kota Kendari, 2015

[21] Rusman. Model-Model Pembelajaran Mengembangkan Profesionalisme Guru. Jakarta: PT. Raja Grafindo Persada, 2013

[22] Arsyad, Azhar. Media Pembelajaran. Jakarta: PT. RajaGrafindo Persada, 2015 